\title{
Productive performance and cost effectiveness of broiler using three different probiotics in the diet
}

\author{
BC Ray, SD Chowdhury* and A Khatun
}

Department of Poultry Science, Bangladesh Agricultural University, Mymensingh-2202, Bangladesh

\begin{abstract}
The experiment reported here was an attempt to evaluate the effect of feeding three different probiotics to broilers on productive performance, meat yield and profitability of rearing for 42 days in an open sided house, at Bangladesh Agricultural University Poultry Farm. Two hundred fifty-six one-day old Indian River straight run broiler chicks were randomly allotted to four dietary treatments each of four replicates of 16 chicks each providing floor space of $1115 \mathrm{~cm}^{2}$ per bird. The basal diet was corn-soya and it was supplemented with different probiotics to make test diets. The dietary treatments were: basal diet $\left(T_{1}\right)$; basal diet supplemented with probiotic-1 (PB-1) at $1.0 \mathrm{~g} / \mathrm{kg}$ feed $\left(\mathrm{T}_{2}\right)$; basal diet supplemented with probiotic-2 (PB-2) at $1.0 \mathrm{~g} / \mathrm{kg}$ feed $\left(\mathrm{T}_{3}\right)$; basal diet supplemented with probiotic-3 (PB-3) at $0.5 \mathrm{~g} / \mathrm{kg}$ feed $\left(\mathrm{T}_{4}\right)$. Birds were fed starter diet from 0-21 days of age and grower diet from 2242 days of age. Records were kept of performance traits and carcass yields by maintaining birds under identical management. Profitability was determined on termination of the trial. Performance and carcass yield data were statistically analyzed employing SAS Computer Package Program (SAS, 2009). Results showed no variation $(P>0.05)$ in growth performance and meat yield characteristics of commercial broilers irrespective of types of probiotic supplementation. However, feed intake increased $(P<0.05)$ due to supplementation of probiotics. Although higher cost $(p<0.05)$ incurred due to addition of probiotics in the diet, such an addition increased profit. Profit over control was BDT 12.20/bird (BDT 5.10/kg) in PB1, BDT 18.70/bird (BDT 7.40/kg) in PB-2 and BDT 17.10/bird (BDT 6.40/kg) in PB-3 group. The profit was higher in all the treated groups over control indicating that the use of probiotics irrespective of type was profitable and cost effective.
\end{abstract}

Key words: commercial broiler, probiotics, performance, meat production, profitability

Bangladesh Animal Husbandry Association. All rights reserved.

Bang. J. Anim. Sci. 2019. 48 (2):85-91

\section{Introduction}

A tendency among the people to get higher gain in body weight from the commercial broilers within the shortest possible time has encouraged the scientists to evolve high yielding broiler strains. Researchers are successful in enhancing body weight gain with lowest feed conversion ratio (FCR). Having such genetically improved stocks, further improvement by dietary intervention has got attention. The use of a number of feed additives and/or growth promoters was in practice for a long time. Several types of antibiotics at sub-therapeutic levels in the diet were the major actors for enhancing growth but their use is being highly criticized due to microbial resistance (Menten, 2001; Sinol et al., 2012). This has led to the use of alternatives to antibiotics in poultry nutrition. Among the alternatives, probiotics are considered worldwide as safe (Roy, 2018; Junaid et al., 2018). Of course, their effects on productive traits differ because of a number of factors. These are the survival and stability of probiotic organisms, the strain, host specifity, manufacturing process, dose frequency, health and nutritional status of birds, the age, physiological stress level and genetics of the host (Chichlowski et al., 2007; Aalaei et el., 2018). Several authors reported beneficial effects of probiotic administration (Corrêa et al., 2003; Vargas et al., 2002), whereas others found no improvement when probiotics were used (Yong et al., 2016; Hossain et al., 2012). Recently, Al-Khalaifa et al. (2019) conducted an experiment and found no effect on productive performance of birds from feeding Bacillus coagulans and Lactobacillus in the diet. Use of probiotics in the diet obviously increases feed cost, but economic data in the literature are scarce. It is therefore interesting to find out at least a few preparations of probiotics that would increase profit margin in spite of making production costly. The experiment reported here was an attempt to make a comparison of three

*Corresponding author: drsdchow@gmail.com 
types of probiotics available in Bangladesh to examine their efficacy on performance in one hand and cost effectiveness on the other.

\section{Materials and Methods}

\section{Experimental birds, housing and design}

A total of 256 Indian River straight run broiler chicks were allocated to four dietary treatments in four replicate pens each of 16 birds in an open sided house. The dietary treatments for comparison were: (1) a corn-soya based basal diet (control); (2) basal diet supplemented with probiotic-1 (PB-1) at $1.0 \mathrm{~g} / \mathrm{kg}$ feed; (3) basal diet supplemented with probiotic-2 (PB-2) at $1.0 \mathrm{~g} / \mathrm{kg}$ feed and (4) basal diet supplemented with probiotic-3 (PB-3) at $0.5 \mathrm{~g} / \mathrm{kg}$ feed. Dietary inclusions were those recommended by manufacturers. The experiment was arranged following the principles of completely randomized design (CRD). Each bird was provided with floor space of $1115 \mathrm{~cm}^{2}$. The composition of the probiotics are: PB-1; Lactobacillus spp.: 3.107$10^{8} \mathrm{cfu} / \mathrm{g}$, Bacillus spp.: $3.10^{7}-10^{8} \mathrm{cfu} / \mathrm{g}$ and Saccharomyces: $10^{6}-10^{7}$ cells/g; PB-2; Bacillus subulans $10^{10} \mathrm{cfu} / \mathrm{g}$, Bacillus soagulans $10^{10} \mathrm{cfu} / \mathrm{g}$ and PB-3; Bacillus subtilis- min. $2 \times 10^{9} \mathrm{cfu} / \mathrm{g}$.

\section{Experimental diet}

A corn-soya based basal diet was formulated using available feed ingredients. Starter diet was provided from 1-21 days and grower diet from 22-42 days. Both types of diet were supplied in mash form. The nutrient requirements were satisfied close to the requirements of Indian River commercial broilers.

\section{Management practices}

The birds were subjected to similar care and management throughout the experimental period. Immediately after arrival of day-old chicks, they were weighed and randomly distributed to each pen. Initially, pieces of newspapers were placed and kept for seven days. The birds were illuminated with incandescent bulb for 23 hours for lighting and one hour of dark period was kept throughout the experimental period. During brooding period $34^{\circ} \mathrm{C}$ temperature was maintained initially, thereafter, $2.5^{\circ} \mathrm{C}$ was reduced in each week by adjusting heat source. $\mathrm{A}$ 100-watt electric bulb for each pen was kept for warming the chicks. Room temperature and humidity were measured four times a day by an automatic digital thermo-hygrometer. Strict biosecurity measures were taken. One round tube feeders and one round drinker with a capacity of eight litters were provided in each pen. Feed and water were provided ad libitum. Fresh and clean drinking water were provided and feeders and drinkers were subjected to cleaning when required. Rice husk was used as litter materials at a depth of about $2.5 \mathrm{~cm}$. It was stirred three times daily from the beginning of fourth week until end of the trial to prevent cake formation and minimize dampness.

Table 1: Ingredient and nutrient composition of basal diet

\begin{tabular}{lrr}
\hline $\begin{array}{l}\text { Ingredients } \\
\text { (\% basis) }\end{array}$ & $\begin{array}{c}\text { Broiler } \\
\text { Starter } \\
\text { (0-21 } \\
\text { days) }\end{array}$ & $\begin{array}{l}\text { Broiler } \\
\text { Grower } \\
\text { ( 22-42 } \\
\text { days) }\end{array}$ \\
\hline Corn & 50.63 & 54.23 \\
Protein Concentrate & 8.50 & 7.50 \\
Soybean meal & 33.30 & 29.70 \\
Limestone & 0.80 & 0.80 \\
Dicalcium phosphate & 1.70 & 1.70 \\
Soybean oil & 4.00 & 5.00 \\
Vit-mineral premix & 0.30 & 0.30 \\
Lysine & 0.20 & 0.20 \\
Methionine & 0.20 & 0.20 \\
Enzyme & 0.05 & 0.05 \\
Salt & 0.30 & 0.30 \\
Emulsifier & 0.020 & 0.020 \\
Total & 100.00 & 100.00 \\
\hline Nutrient composition & & 1.34 \\
Energy (ME kcal/kg) & 3011 & 3159 \\
Crude protein, \% & 24.09 & 22.25 \\
Calcium, \% & 0.82 & 0.79 \\
Total phosphorus, \% & 0.51 & 0.49 \\
Av. phosphorus, \% & 1.42 & 1.31 \\
Mysine, \% & 0.61 & 0.58 \\
\hline & 0.91 & 0.87 \\
\hline & & 1.23 \\
\hline
\end{tabular}

Newcastle disease and Infectious bronchitis disease vaccine (MA5+Clone 30 ) was given at $5^{\text {th }}$ day of age. It was followed by a booster dose of similar vaccine at $21^{\text {st }}$ days of age. Infectious bursal disease (Gumboro) vaccine (228E) was given on day 10 followed by a booster dose on $17^{\text {th }}$ day. 
Ray et al. (2019) Bang. J. Anim. Sci. 48 (2):85-91

\section{Performance records}

The broiler chicks were weighed group-wise at the beginning of experiment and then every 7 days intervals until the end of experiment at day 42. The weight was taken in the early morning. Average live weight and the live weight gain of the broiler chicks on different dietary treatments were obtained by calculations. The amounts of feed consumed by experimental broilers in different groups were determined by calculations. Feed conversion ratio was calculated as the unit of feed consumed per unit of body weight gain.

\section{Carcass characteristics}

At the end of feeding trial three broilers having body weight near to pen average from each treatment were taken randomly for the quantitative evaluation of meat yield parameters. To facilitate processing of broilers, feed was withdrawn 8 hours before slaughtering but water was supplied in a regular manner. The birds were killed and allowed to bleed for 5 minutes and immersed in hot water $\left(51-55^{\circ} \mathrm{C}\right)$ for 2 minutes for the ease of feather removal. Dressed broilers were cut into different parts and proportion of cut up parts was converted into percentage.

\section{Economics of production}

Cost benefit analysis was performed at the end of trial to justify the use of probiotics. In calculating the total cost of production, cost of chicks, feed, vaccine, electricity and casual labor were taken into consideration. In addition, for treated groups, cost of test ingredients was added. The cost benefit was calculated as BDT/bird (basis) and BDT/kg live weight basis.

\section{Results and Discussion}

\section{Growth performance}

Table 2 shows the comparison of productive performance of commercial broilers receiving different types of probiotics. Initial live weight of the birds in different dietary groups was almost similar and no significant difference was found in the growth performance among the treated groups. Although no significant difference was apparent, birds on treated group showed higher trends in weight gain and lower trends in FCR. None of the parameters except the feed intake differed $(P>0.05)$ between $T_{3}$ and $T_{4}$ due to supplementation of probiotics in the diet.

No significant improvement in body weight gain was reported by Chen et al. (2009) with Bacillus subtilis and Saccharomyces containing probiotics. No improvement on performance was also reported by Mutus et al. (2006) from a feeding trial that lasted for 42 days when they used Bacillus licheniformis and Bacillus subtilis as dietary probiotic. Karaoglu and Durdag (2005) used Saccharomyces cerevisiae as a dietary probiotic to assess growth performance and found no difference in weight gain. In contrast, Awad et al. (2013) and Gao et al. (2009) reported improved body weight gain upon feeding of lactobacillus containing probiotics. Results of feeding Bacillus subtilis containing probiotics (Molnar et al., 2012) and Lactobacillus containing probiotics (Gao et al., 2009) showed an increase in feed intake similar to the findings of the current study. Bai et al. (2017) conducted an experiment with Bacillus subtilis containing probiotics for a period of 42 days and observed increased feed intake.

Table 2: Effect of feeding three different probiotics on production performances of broiler chickens $(0-42$ days)

\begin{tabular}{lrrrrr}
\hline Treatment & \multicolumn{1}{c}{$\mathbf{T}_{\mathbf{1}}$} & \multicolumn{1}{c}{$\mathbf{T}_{\mathbf{2}}$} & \multicolumn{1}{c}{$\mathbf{T}_{\mathbf{3}}$} & \multicolumn{1}{c}{$\mathbf{T}_{\mathbf{4}}$} & P-value \\
\hline Day-old chick weight $\mathbf{( g )}$ & $38 \pm 0.31$ & $38 \pm 0.32$ & $38 \pm 0.31$ & $39 \pm 0.16$ & 0.5829 \\
Final weight $\mathbf{( g )}$ & $1846 \pm 7.00$ & $1988 \pm 28.14$ & $2055 \pm 53.98$ & $2057 \pm 94.18$ & 0.0848 \\
Weight gain $\mathbf{( g )}$ & $1808 \pm 36.92$ & $1950 \pm 28.31$ & $2017 \pm 54.14$ & $2018 \pm 94.02$ & 0.0852 \\
Feed intake $\mathbf{( g )}$ & $3350^{\mathrm{b}} \pm 43.91$ & $3423^{\mathrm{ab}} \pm 28.66$ & $3475^{\mathrm{a}} \pm 18.00$ & $3534^{\mathrm{a}} \pm 53.57$ & 0.0317 \\
Feed conversion ratio & $1.86 \pm 0.032$ & $1.75 \pm 0.025$ & $1.73 \pm 0.052$ & $1.76 \pm 0.054$ & 0.2360 \\
\hline
\end{tabular}

* $\mathrm{T}_{1}$-Control, $\mathrm{T}_{2}=$ PB-1 (Lactobacillus spp.: $3.10^{7}-10^{8} \mathrm{cfu} / \mathrm{g}$, Bacillus spp.: $3.10^{7}-10^{8} \mathrm{cfu} / \mathrm{g}$ and Saccharomyces: $10^{6}-10^{7}$ cells $/ \mathrm{g}$ ), $\mathrm{T}_{3}=\mathrm{PB}-2$ (Bacillus subulans $10^{10} \mathrm{cfu} / \mathrm{g}$, Bacillus soagulans $10^{10} \mathrm{cfu} / \mathrm{g}$ ), T4=PB-3 (Bacillus subtilis- min. $2 \times 10^{9} \mathrm{cfu} / \mathrm{g}$ ), Means with superscripts having no common alphabet in the same row differ significantly at the stated level of probability. Value indicate- mean \pm standard error. 
However, Patel et al. (2015) showed that feed intake was not affected by feeding multi-strain probiotics (Lactobacillus plantarum, Lactobacillus bulgaricus, Lactobacillus acidophilus, Lactobacillus casei, Streptococcus thermophilus, Streptococcus faecium, Bifidobacterium bifidum, Torulopsis spp. and Aspergillus oryzae). No effect on feed intake was also in line with the study of Willis and Reid (2008) upon dietary probiotic feeding. No significant variation reported in feed conversion in a trial of Junaid et al. (2018) upon feeding Lactobacillus acidophilus and Bifidobacterium bifidi containing probiotics over a period of 42 days. On the other hand, He et al. (2019) expressed improved FCR $(P<0.05)$ by feeding a mixture of Bacillus subtilis, Bacillus licheniformis and Saccharomyces cerevisiae in the diet for a period of 42 days.

\section{Edible meat yield characteristics}

Application of dietary probiotics did not cause any significant changes in meat yield characteristics of chicken (Table 3). This was an indication that inclusion of dietary probiotics did not alter meat yield characteristics.
A study was conducted to evaluate the potential of Bacillus subtilis based probiotic and no significant improvement was noticed in carcass characteristics (Mahmoud et al., 2017). Patel et al. (2015) reported no changes in edible organ weights fed probiotics containing diet. In agreement with our results, Anjum et al. (2005) found no significant improvement in dressing percentage of broiler chickens because of dietary probiotic supplementation. In addition, Racevičiūtè-Stupelienè et al. (2007) found similar carcass and breast meat yield in birds fed diet with or without probiotic based on Saccharomyces cervisiae. However, other research findings (Kabir et al., 2004; Farhoomand and Dadvend, 2007) showed that probiotic inclusion to broiler diets increased dressing percentage. No significant change in abdominal fat was found in this study. This was in agreement with the earlier findings (Aksu et al., 2005; Karaoglu and Durdag, 2005; Farhoomand and Dadvend, 2007 and Racevičiūtè-Stupelienè et al., 2007).

Table 3: Effect of feeding three different probiotics on meat yield of broiler chickens (0-42 days)

\begin{tabular}{lccccc}
\hline Parameters (\%) & $\mathbf{T}_{\mathbf{1}}$ & $\mathbf{T}_{\mathbf{2}}$ & $\mathbf{T}_{\mathbf{3}}$ & $\mathbf{T}_{\mathbf{4}}$ & P-value \\
\hline Dressed weight & $70.74 \pm 0.557$ & $71.56 \pm 1.164$ & $71.34 \pm 0.505$ & $68.93 \pm 0.971$ & 0.1951 \\
Breast & $22.79 \pm 0.569$ & $23.64 \pm 1.233$ & $21.89 \pm 1.032$ & $22.03 \pm 1.172$ & 0.6292 \\
Thigh & $13.06 \pm 0.908$ & $13.72 \pm 0.216$ & $12.95 \pm 1.279$ & $12.55 \pm 0.233$ & 0.7793 \\
Drumstick & $9.51 \pm 0.163$ & $9.83 \pm 0.666$ & $10.83 \pm 0.169$ & $9.9 \pm 0.176$ & 0.1400 \\
Heart & $0.55 \pm 0.026$ & $0.53 \pm 0.008$ & $0.55 \pm 0.028$ & $0.50 \pm 0.057$ & 0.7232 \\
Liver & $2.27 \pm 0.250$ & $2.50 \pm 0.046$ & $2.52 \pm 0.157$ & $2.28 \pm 0.053$ & 0.5107 \\
Gizzard & $1.910 \pm 0.082$ & $1.66 \pm 0.041$ & $1.87 \pm 0.147$ & $1.88 \pm 0.107$ & 0.3432 \\
Giblet & $4.74 \pm 0.262$ & $4.69 \pm 0.093$ & $4.95 \pm 0.278$ & $4.67 \pm 0.173$ & 0.7766 \\
Head & $1.25 \pm 0.073$ & $1.23 \pm 0.026$ & $1.21 \pm 0.051$ & $1.17 \pm 0.029$ & 0.7055 \\
Wing & $8.47 \pm 0.149$ & $8.04 \pm 0.303$ & $7.98 \pm 0.073$ & $7.69 \pm 0.337$ & 0.2359 \\
Neck & $4.34 \pm 0.349$ & $4.90 \pm 0.282$ & $5.32 \pm 0.174$ & $4.73 \pm 0.299$ & 0.1871 \\
Fat & $1.01 \pm 0.430$ & $0.80 \pm 0.232$ & $0.92 \pm 0.217$ & $0.43 \pm 0.087$ & 0.4965 \\
\hline
\end{tabular}

${ }^{*} \mathrm{~T}_{1}$-Control, $\mathrm{T}_{2}=$ PB-1 (Lactobacillus spp.: $3.10^{7}-10^{8} \mathrm{cfu} / \mathrm{g}$, Bacillus spp.: $3.10^{7}-10^{8} \mathrm{cfu} / \mathrm{g}$ and Saccharomyces: $10^{6}-10^{7}$ cells $/ \mathrm{g}$ ), $\mathrm{T}_{3}=\mathrm{PB}-2$ (Bacillus subulans $10^{10} \mathrm{cfu} / \mathrm{g}$, Bacillus soagulans $10^{10} \mathrm{cfu} / \mathrm{g}$ ), $\mathrm{T}_{4}=\mathrm{PB}-3$ (Bacillus subtilis- $\left.\min .2 \times 10^{9} \mathrm{cfu} / \mathrm{g}\right)$, none of the variables showed significant difference $(P>0.05)$, Value indicate- mean \pm standard error. 
Ray et al. (2019) Bang. J. Anim. Sci. 48 (2):85-91

Table 4: Economic analysis and cost-effectiveness of feeding probiotics

\begin{tabular}{|c|c|c|c|c|c|}
\hline Parameters & $\mathbf{T}_{1}$ & $\mathbf{T}_{\mathbf{2}}$ & $\mathbf{T}_{\mathbf{3}}$ & $\mathbf{T}_{4}$ & P-value \\
\hline $\begin{array}{l}\text { (a) Feed cost } \\
\text { (BDT/bird) }\end{array}$ & $129.00^{\mathrm{b}} \pm 1.69$ & $131.90^{\mathrm{ab}} \pm 1.11$ & $133.90^{\mathrm{a}} \pm 0.69$ & $136.20^{\mathrm{a}} \pm 2.07$ & 0.0318 \\
\hline $\begin{array}{l}\text { (b) Probiotic cost } \\
\text { (BDT/bird) }\end{array}$ & $0.00^{d} \pm 0.00$ & $2.00^{\mathrm{a}} \pm 0.02$ & $1.57^{b} \pm 0.01$ & $1.13^{\mathrm{c}} \pm 0.0158$ & $<0.0001$ \\
\hline $\begin{array}{l}\text { (c) Chick cost } \\
\text { (BDT/bird) }\end{array}$ & 40.00 & 40.00 & 40.00 & 40.00 & - \\
\hline $\begin{array}{l}\text { (d) Other cost } \\
\text { (BDT/bird) }\end{array}$ & 25.00 & 25.00 & 25.00 & 25.00 & - \\
\hline $\begin{array}{l}\text { (e) Total cost } \\
\text { (BDT/bird) }\end{array}$ & $194.10^{\mathrm{b}} \pm 1.69$ & $199.00^{\mathrm{a}} \pm 1.12$ & $200.50^{\mathrm{a}} \pm 0.70$ & $202.30^{\mathrm{a}} \pm 2.08$ & 0.0125 \\
\hline \multicolumn{6}{|l|}{$(a+b+c+d)$} \\
\hline $\begin{array}{l}\text { (f) Total cost (BDT/kg } \\
\text { body weight) }\end{array}$ & $105.20 \pm 1.86$ & $100.10 \pm 1.35$ & $97.80 \pm 2.79$ & $98.80 \pm 3.46$ & 0.2119 \\
\hline $\begin{array}{l}\text { (g) Sale price } \\
\text { (BDT/bird @120/kg } \\
\text { live wt.) }\end{array}$ & $221.50 \pm 4.44$ & $238.60 \pm 3.38$ & $246.60 \pm 6.48$ & $246.80 \pm 11.30$ & 0.0849 \\
\hline $\begin{array}{l}\text { (h) Profit (BDT/bird) } \\
\text { (g-e) }\end{array}$ & $27.40 \pm 3.94$ & $39.60 \pm 3.20$ & $46.10 \pm 6.74$ & $44.50 \pm 9.53$ & 0.2083 \\
\hline (i) Profit (BDT/kg) & $14.80 \pm 1.86$ & $19.90 \pm 1.35$ & $22.20 \pm 2.79$ & $21.20 \pm 3.46$ & 0.2119 \\
\hline \multicolumn{6}{|l|}{ (h/live weight of bird) } \\
\hline $\begin{array}{l}\text { (j) Profit over control } \\
\text { (BDT/bird) }\end{array}$ & - & 12.20 & 18.70 & 17.10 & - \\
\hline $\begin{array}{l}\text { (k) Profit over control } \\
(\mathrm{BDT} / \mathrm{kg})\end{array}$ & - & 5.10 & 7.40 & 6.40 & - \\
\hline
\end{tabular}

* $\mathrm{T}_{1}$-Control, $\mathrm{T}_{2}=$ PB-1 (Lactobacillus spp.: $3 \cdot 10^{7}-10^{8} \mathrm{cfu} / \mathrm{g}$, Bacillus spp.: $3 \cdot 10^{7}-10^{8} \mathrm{cfu} / \mathrm{g}$ and Saccharomyces: $10^{6}-10^{7}$ cells $/ \mathrm{g}$ ), $\mathrm{T}_{3}=\mathrm{PB}-2$ (Bacillus subulans $10^{10} \mathrm{cfu} / \mathrm{g}$, Bacillus soagulans $10^{10} \mathrm{cfu} / \mathrm{g}$ ), $\mathrm{T}_{4}=\mathrm{PB}-3$ (Bacillus subtilis- min. $2 \times 10^{9} \mathrm{cfu} / \mathrm{g}$ ), Body weight of $\mathrm{T}_{1}=1846 \mathrm{~g}, \mathrm{~T}_{2}, 1988 \mathrm{~g}, \mathrm{~T}_{3}=2055 \mathrm{~g}, \mathrm{~T}_{4}=2057 \mathrm{~g}$, BDT=Bangladeshi Taka, Means with superscripts having no common alphabet in the same row differ significantly at the stated level of probability. Value indicate- mean \pm standard error.

\section{Economics of feeding probiotics}

The cost of production per live broiler was observed higher $(P<0.05)$ in the treated groups, as would be expected. Although higher cost incurred in probiotics fed groups, it was minimized due to the increased sale price of the birds. The additional cost incurred for probiotic feeding over control was BDT 2.00/bird in PB-1, BDT $1.57 /$ bird in PB-2 and BDT $1.13 /$ bird in PB-3 treated group. It appears from Table 4 that the profit per bird over control was BDT 12.20 /bird in PB-1, BDT $18.70 /$ bird in PB-2 and $17.10 /$ bird in PB-3 group. Despite the highest cost, the income generated from the broilers that consumed probiotics was numerically higher but was not statistically significant. Net profit over control was higher in all the probiotic treated groups. Patel et al. (2015) found higher profit over control upon multi-strain probiotic feeding; BDT 1.63 with a dose rate of $50 \mathrm{~g} /$ ton feed and BDT 5.40 with a dose rate of $100 \mathrm{~g} /$ ton feed. Roy (2018) conducted a series of experiments using probiotics and showed better profit in probiotics treated groups over control in all trials. Multiple trials showed that, profit in Bacillus subtilis DSM $17299\left(1.6 \times 10^{9} \mathrm{cfu} / \mathrm{g}\right)$ over control was BDT $13.00 / \mathrm{kg}$ live weight. In another trial, he showed that profit over control in Bacillus subtilis DSM $17299\left(1.6 \times 10^{9} \mathrm{cfu} / \mathrm{g}\right)$ was BDT $12.15 / \mathrm{kg}$ and Bacillus subtilis PB6 @ $1 \times 10^{9} \mathrm{cfu} / \mathrm{g}$ was BDT $12.31 / \mathrm{kg}$. He also concluded both Bacillus subtilis 
@ $4 \times 10^{10}$ and Bacillus licheneformes @ $4 \times 10^{10}$ ) contained diet showed BDT $9.31 / \mathrm{kg}$ profit over control and Saccharomyces cerevisiae probiotic fed birds reflected a profit of BDT $6.80 / \mathrm{kg}$ body weight over control.

\section{Conclusion}

Feeding probiotics at three preparations increased feed intake of broilers without altering other growth parameters and meat yield characteristics. An increasing trend in body weight and decreasing trend in FCR contributed to the profit in probiotic treated broilers. Dietary inclusion of three different probiotics as considered in the study increased profit over control and probiotic containing Bacillus subulans and Bacillus soagulans (PB-2) was found to be most cost effective.

\section{Acknowledgement}

The authors would like to express thanks to Ministry of Education (MoE), Govt. of the People's Republic of Bangladesh for funding the research.

\section{Conflict of interest}

The authors have no conflict of interest to declare.

\section{References}

Aalaei M, A Khatibjoo, M Zaghari, K Taherpou, MA Gharaei and M Soltani (2018). Effect of singleand multi-strain probiotics on broiler breeder performance, immunity and intestinal toll-like receptors expression. Journal of Applied Animal Research 47(1):236-242.

Al-Khalaifa $\mathrm{H}$, A Al-Nasser, T Al-Surayee, S AlKandari, N Al-Enz , T Al-Sharrah, G Ragheb, S Al-Qalaf and A Mohammed (2019). Effect of dietary probiotics and prebiotics on the performance of broiler chickens. Poultry Science (10): 4465-4479.

Anjum MI, AG Khan, A Azim and M Afzal (2005) Effect of dietary supplementation of multistrain probiotic on broiler growth performance. Pakistan Veterinary Journal 1:25-29.

Awaad MHH, AM Atta, MA Elmenawey, HB Gharib, WAA El-Ghany and AA Nada (2013). The effect of a combination of (1-3) D-Glucan and Propionibacterium granulosum on productive performance and immune modulation of immune compromised and nonimmunocompromised broiler chickens. Veterinary World 6(1):31-38.

Bai K, Q Huang, J Zhang, J He, L Zhang and T Wang (2017). Supplemental effects of probiotic Bacillus subtilis fmbJ on growth performance, antioxidant capacity, and meat quality of broiler chickens. Poultry Science 969(1):7482.
Chen KL, WL Kho, SH You, RH Yeh, SW Tang and CW Hsieh (2009). Effects of Bacillus subtilis var. natto and Saccharomyces cerevisiae mixed fermented feed on the enhanced growth performance of broilers. Poultry Science, 88:309-315.

Chichlowski M, J Croom, BW Mcbride, GB Havenstein and MD Koci (2007). Metabolic and physiological impact of probiotics or direct-fed microbials on poultry-A brief review of current knowledge. International Journal of Poultry Science 6:694-704.

Correa G, A Gomes, A Correa, A Salles and E Mattos (2003). Effect of antibiotic and probiotic on the performance and carcass yield of broilers. Arquivo Brasileiro de Medicina Veterinária e Zootecnia 55:467-473.

Farhoomand P and A Dadvend (2007). Carcass weight, growth performance and internal organ size of broilers fed graded levels of Saccharomycese cerevisiae supplemented diets. Pakistan Journal of Biological Sciences 10:1870-1874

Gao J, HJ Zhang, SG Wu, SH Yu, I Yoon, D Moore, YP Gao, HJ Yan and GH Qi (2009). Effect of Saccharomyces cerevisiae fermentation product on immune function of broilers challenged with Eimeria tenella. Poultry Science 88: 2121-2151.

He T, S Long, S Mahfuz, D Wu, X Wang, X Wei and X Piao (2019). Effects of Probiotics as Antibiotics Substitutes on Growth Performance, Serum Biochemical Parameters, Intestinal Morphology, and Barrier Function of Broilers. Animals 9(11):985

Hossain ME, GM Kim, SK Lee and CJ Yang (2012). Growth performance, meat yield, oxidative stability, and fatty acid composition of meat from broilers fed diets supplemented with a medicinal plant and probiotics. Asian Australasian Journal Animal Sciences 25:11591168.

Junaid N, A Biswas, $M$ Kumawat and $A B$ Mandal (2018). Production performance, immune response and carcass traits of broiler chickens fed diet incorporated with probiotics. Indian Journal Animal Research 0:1-6.

Kabir SM, MM Rahman, MB Rahman, M Rahman and SU Ahmed (2004). The dynamic of probiotics on growth performance and immune response in broilers. International Journal of Poultry Science 3:361-364.

Karaoglu M and $H$ Durdag (2005). The influence of dietary probiotic (Saccharomyces cerevisiae) supplementation and different slaughter age on the performance, slaughter and carcass properties of broilers. International Journal of Poultry Science 4:309-316.

Molnar AK, B Podmaniczky, P Kurti, I Tenk, R Glavits, GY Virag and ZS Szabo (2012). Effect of different concentrations of Bacillus subtilis on growth performance, carcass quality, gut microflora and immune response of broiler chickens. British Poultry Science 52: 658-665. 
Ray et al. (2019) Bang. J. Anim. Sci. 48 (2):85-91

Mahmoud KZ, BS Obeidata, MZ Al-Sadia and S.R. Hatahetb (2017). Effect of Bacillus subtilis supplementation and dietary crude protein level on growth performance and intestinal morphological changes of meat type chicken. Livestock Science 195:99-104

Menten JFM (2001). Aditivos alternativos na nutrição de aves:Probióticos e Prebióticos. Sociedade Brasileira de Zootecnia-A produção animal na visão dos brasileiros, Piracicaba. Foundation Luiz de Queiroz 141-157.

Mutuş R, N Kocabaçli, M Alp, N Acar, M Eren and SS Gezen (2006). The effect of dietary probiotic supplementation on tibial bone characteristics and strength in broilers. Poultry Science 85:1621-1625.

Patel SG, AP Raval, S Bhagwat and SS Joshi (2015). Effects of Probiotics Supplementation on Growth Performance, Feed Conversion Ratio and Economics of Broilers. Journal of Animal Research 5(1):155-160.

Racevičiūtè-Stupelienė A, V Šašytè, R Gružauskas and A Šimkus (2007). Influence of probiotic preparation YEASTURE-W on the productivity and meat quality of broiler chickens. Biotechnology Animal Husbandry 23:543-550.

Roy BC (2018). Evaluation of probiotics, prebiotics and synbiotics as alternatives to antibiotics in the diet of commercial broilers. PhD Thesis, Department of Poultry Science, Bangladesh Agricultural University, Mymensingh.
SAS Institute, Inc. 2009: SAS OnlineDoc $®$ Version 9.1.3, Cary, NC, USA

Sinol S, SL Ingale, YW Kim, JS Kim, KH Kima, JD Lohakarea, EK Kim, HS Kim, MH Ryu, IK Kwon and BJ Chae (2012). Effect of supplementation of Bacillus subtilis LS 1-2 to broiler diets on growth performance, nutrient retention, caecal microbiology and small intestinal morphology. Research in Veterinary Science 93: 264-268.

Vargas JJG, RS Toledo, LFT Albino, HS Rostango, JE Oliveira and DCO Carvalho (2002). Broiler carcass characteristics, subjected to diets containing probiotics, prebiotics and antibiotics. In: XXXIX-Annual Meeting of the SBZ, Recife. Anais ... Recife. CD ROM.

Willis WL and L Reid (2008). Investigating the effects of dietary probiotic feeding regimens on broiler chicken production and Campylobacter jejuni presence. Poultry Science 87(4):606611.

Yong HP, H Farizal, R Chandraprasad, PS Kim, YG Chee, SL Theam, NW Wan, and TL Min (2016). Application of probiotics for the production of safe and high-quality poultry meat. Korean Journal Food Science Animal Resources 36(5):567-576 